\title{
Sposoby uaktualniania charakterystyki wydobywczej odwiertu gazowego przez okresową modyfikację wielkości współczynnika przepływu laminarnego
}

\section{Periodic updating of the laminar flow coefficient of the gas well deliverability formula}

\author{
Tadeusz Szpunar, Paweł Budak \\ Instytut Nafty i Gazu - Państwowy Instytut Badawczy
}

\begin{abstract}
STRESZCZENIE: Rozpoczęcie eksploatacji każdego nowego odwiertu gazowego wymaga wykonania wcześniejszej oceny jego możliwości produkcyjnych, to jest określenia wielkości przypływu gazu do odwiertu przy danej depresji. Jest to podstawą planowania eksploatacji gazu z danego odwiertu. Oceny takiej dokonuje się poprzez przeprowadzenie w odwiertach klasycznych i zmodyfikowanych testów produkcyjnych. Testy produkcyjne wykonywane są również w sytuacjach, gdy zachodzi potrzeba uaktualnienia możliwości wydobywczych złoża lub poszczególnych odwiertów. Wadą tego typu testów jest konieczność przerwania eksploatacji gazu i zamykania odwiertów w celu uzyskania, między innymi, warunków stabilizacji ciśnień, a czas zamknięcia zależy od przepuszczalności złoża i w przypadku złóż o małej przepuszczalności może być długi. Interpretacja testów produkcyjnych oparta jest na teoretycznej zależności określanej mianem tzw. formuły dwuczłonowej. Jeżeli jej współczynniki przepływu laminarnego i turbulentnego ( $a$ i $b$ ) są znane, to możliwe jest podanie wielkości wydobycia potencjalnego gazu przy danej depresji, czyli zaplanowanie eksploatacji odwiertu. Okresowe uaktualnianie postaci formuły dwuczłonowej wymagane jest zarówno przez przepisy, jak i ze względów technicznych. Niedogodności związane z przeprowadzeniem klasycznych testów produkcyjnych służących do ustalenia charakterystyki wydobywczej odwiertu spowodowały, że opracowano inne metody wykonywania testów produkcyjnych, mające na celu skrócenie czasu pomiarów. W artykule podano sposoby przybliżonego określania współczynnika przepływu laminarnego formuły dwuczłonowej bez potrzeby zamykania odwiertu i pomiaru przebiegu odbudowy ciśnienia w funkcji czasu w celu oceny średniego ciśnienia złożowego. Znajomość współczynnika przepływu laminarnego pozwala na uaktualnienie postaci formuły dwuczłonowej, a na tej podstawie korygowanie przewidywanej wielkości dopływu gazu do odwiertu eksploatacyjnego przy określonej depresji. Zaletą prezentowanych metod jest skrócenie czasu wykonywania testowań, co powinno przynosić wymierne korzyści ekonomiczne poprzez ograniczenie kosztów przestoju odwiertu gazowego. Podano przykłady obliczeniowe dla odwiertów gazowych z krajowego przemysłu naftowego. Otrzymane wyniki obliczeń proponowanymi sposobami są w przybliżeniu zgodne z wynikami uzyskanymi przy użyciu klasycznych testów wielocyklowych. Podano również sposób określania współczynnika przepływu laminarnego i turbulentnego metodą analityczną przy dopuszczeniu różnego od 2 wykładnika formuły dwuczłonowej oraz warunki stosowalności tego sposobu. Zilustrowano to przykładami obliczeń dla odwiertów gazowych z krajowego przemysłu naftowego.
\end{abstract}

Słowa kluczowe: możliwości produkcyjne odwiertu gazowego, test wielocyklowy, współczynnik przepływu laminarnego, współczynnik przypływu turbulentnego, ciśnienie denne stabilizacji, ustabilizowane natężenie przypływu.

\begin{abstract}
The deliverability of each gas well must be known before the gas production is started which means that the relation between gas flow rate and bottom hole drown down pressure must be known in advance. The classical, isochronal and modified isochronal tests are used for this purpose. All of these tests should be able to calculate the coefficients of deliverability equation but laminar flow coefficient in particular because the turbulent flow coefficient doesn't change much during well production period. In the paper proposed are techniques for approximate evaluation of laminar flow coefficient without closing the well for pressure build up and for evaluation of the average reservoir pressure. The laminar flow coefficient must be known to evaluate the relation between the gas flow rate and the drown down pressure. Provided are examples of calculation procedure using each of the techniques. Data from domestic gas industry were used to demonstrate usability of proposed methods. Obtained results of calculation of laminar flow coefficients using the proposed techniques are very close to results of the standard multi rate gas well deliverability test. The proposed method for calculation of laminar flow coefficient assumes that the exponent in deliverability formula may be different than two and that the flow rates must be equal to geometric average of the proceeding and the following rate which require to use the flow rate control choke. No such
\end{abstract}

Autor do korespondencji: P. Budak, e-mail:pawel.budak@inig.pl

Artykuł nadesłano do Redakcji: 08.11.2019 r. Zatwierdzono do druku: 30.03.2020 r. 
tests are used in industry but among hundreds of test data the authors succeeded to find a dozen or so which accidentally satisfied this requirements. The paper also provides another simple procedures for calculation of laminar flow coefficient which do not require closing the gas well for pressure buildup.

Key words: gas well deliverability, multi rate gas well test, laminar flow coefficient, turbulent flow coefficient, stabilized down hole pressure, stabilized flow rate.

\section{Wstęp}

Przystąpienie do eksploatacji każdego nowego odwiertu gazowego wymaga wykonania wcześniejszej oceny jego możliwości produkcyjnych. Ocena ta polega na uruchomieniu eksploatacji gazu kolejno przy przynajmniej trzech natężeniach przypływu kontynuowanych do uzyskania ustabilizowanego stanu dopływu. W przypadku klasycznego testu produkcyjnego po uzyskaniu stabilizacji ciśnienia dennego ruchowego po okresie przypływu odwiert zamykany jest na czas potrzebny do odbudowy ciśnienia do wartości początkowego ciśnienia złożowego w przypadku nowych odwiertów lub średniego ciśnienia w obszarze drenażu w przypadku odwiertów już wcześniej eksploatowanych. Wymagane jest zatem, aby każdy cykl przypływu rozpoczynał się przy jednakowej początkowej wartości ciśnienia, to jest przy początkowym ciśnieniu złożowym (odwierty nowe) lub przy średnim ciśnieniu w obszarze drenażu (odwierty już eksploatowane).

W przypadku złóż o małej przepuszczalności czas oczekiwania na stabilizację zarówno ciśnienia przypływu, jak i ciśnienia odbudowy po zakończeniu cyklu przypływu może być bardzo długi, co wymaga wyłączenia odwiertu z eksploatacji. Pomiary takie jak opisane wyżej wykonywane są, ilekroć zachodzi potrzeba uaktualnienia możliwości wydobywczych złoża lub poszczególnych odwiertów. Ich wadą jest konieczność przerwania eksploatacji i zamykania odwiertu w celu uzyskania stabilizacji ciśnienia, a czas zamknięcia zależy od przepuszczalności złoża i w przypadku złóż o małej przepuszczalności może być zbyt długi. Niedogodności związane z przeprowadzeniem klasycznych testów produkcyjnych służących do ustalenia charakterystyki wydobywczej odwiertu spowodowały, że opracowano inne metody wykonywania testów produkcyjnych, mające na celu skrócenie czasu pomiarów. Należą do nich kolejno:

- metoda izochroniczna, polegająca na skróceniu czasu przypływu gazu przy każdej z wydajności do jednej wartości, natomiast odbudowa ciśnienia po zakończeniu cyklu przypływu nadal kontynuowana jest do osiągnięcia stabilizacji, czyli do uzyskania ciśnienia początkowego złożowego (odwierty nowe) lub średniego ciśnienia w obszarze drenażu (testy wykonywane w trakcie eksploatacji złoża);

- zmodyfikowany test izochroniczny, w którym czasy trwania przypływu i odbudowy ciśnienia są sobie równe, a jedynie ostatni cykl przypływu kontynuowany jest do stabilizacji ciśnienia i wydatku. Interpretacja danych zmodyfikowanego testu izochronicznego polega na naniesieniu w prostokątnym układzie współrzędnych wielkości różnicy kwadratów początkowego lub średniego ciśnienia złożowego w obszarze drenażu (zależnie, czy odwiert jest nowy, czy już eksploatowany) podzielonej przez $Q_{N i}$ od $Q_{N i}$ oraz aproksymacji przebiegu punktów linią prostą metodą najmniejszych kwadratów.

Niekiedy w celu poprawienia dokładności obliczeń zamiast różnicy kwadratów ciśnień stosuje się tzw. pseudociśnienia $m(p)$. W przypadku stosowania pseudociśnień współczynniki formuły dwuczłonowej postaci

$$
m(\bar{p})-m\left(p_{d r_{i}}\right)=a_{t} Q_{N i}+b Q_{N i}^{2}
$$

dla stanu nieustalonego obliczane są za pomocą wzorów otrzymanych metodą najmniejszych kwadratów:

$$
a_{t}=\frac{\sum_{1}^{N} \frac{\Delta m(p)_{i}}{Q_{N_{i}}} \sum_{1}^{N} Q_{N_{i}}^{2}-\sum_{1}^{N} Q_{N_{i}} \sum_{1}^{N} \Delta m(p)_{i}}{N \sum_{1}^{N} Q_{N_{i}}^{2}-\left(\sum_{1}^{N} Q_{i}\right)^{2}}
$$

oraz

$$
b=\frac{N \sum_{1}^{N} \Delta m(p)_{i}-\sum_{1}^{N} Q_{N_{i}} \sum_{1}^{N} \frac{\Delta m(p)_{i}}{Q_{N_{i}}}}{N \sum_{1}^{N} Q_{N_{i}}^{2}-\left(\sum_{1}^{N} Q_{N i}\right)^{2}}
$$

gdzie:

$a_{t}$ - współczynnik przepływu laminarnego (laminar flow factor),

$b$ - współczynnik przepływu turbulentnego (turbulent flow factor),

$Q_{N_{i}}$ - wydatek $i$-tego okresu przypływu gazu,

$N$ - liczba cykli przypływu,

$\bar{p}$ - średnie ciśnienie złożowe w obszarze drenażu odwiertu,

$p_{d r_{i}}-$ ciśnienie końcowe $i$-tego cyklu przypływu,

$\Delta m\left(p_{i}\right)=m(\bar{p})-m\left(p_{d r_{i}}\right)$ oraz $m(p)=2 \int_{p_{b}}^{p} \frac{\bar{p} \mathrm{dp}}{\mu(\bar{p}, \mathrm{~T}) \mathrm{Z}(\bar{p}, \mathrm{~T})}$

$\mu_{g}(\bar{p}, T)$ - lepkość gazu w warunkach złożowych,

$Z(\bar{p}, T)$ - współczynnik uwzględniający odstępstwa zachowania gazu od zachowania gazu idealnego.

Współczynnik $b$ odczytać można jako nachylenie prostej wykresu $\Delta m\left(p_{i}\right) / Q_{N i}$ vs. $Q_{N i}$. 
W przypadku posługiwania się formułą dwuczłonową postaci:

$$
\bar{p}^{2}-p_{d r_{i}}^{2}=\bar{a}_{t} Q_{N i}+\bar{b} Q_{N i}^{2}
$$

wzory analogiczne do (2) i (3) mają postać identyczną, z tym że $\Delta m(p)$ należy zastąpić przez $\Delta p^{2}$.

Do wzoru (2) dodano indeks $t$ w celu zaznaczenia, że dotyczy on stanu nieustalonego. Wielkość a dla stanu ustalonego określana jest na podstawie współrzędnej punktu przecięcia linii prostej równoległej do linii $\Delta m(p) / Q_{N i \text { vs. }} Q_{N i}$ lub $\Delta p^{2} / Q_{N i \text { vs. }} Q_{N i}$ poprowadzonej przez punkt odpowiadający ustalonemu stanowi wydatku i ciśnienia.

Również zmodyfikowany test izochroniczny wymaga zamknięcia odwiertu oraz przerwania jego eksploatacji w celu rejestracji ciśnień odbudowy.

Oprócz powyżej opisanych testów produkcyjnych wykorzystywany jest niekiedy tzw. test flow after flow, który polega na eksploatacji odwiertu przy szeregu stałych wydatkach kontynuowanych do stanu ustalonego oraz pomiarze odpowiadających tym wydatkom ustabilizowanych ciśnień dennych ruchowych. W teście tym, po zakończeniu okresu przypływu gazu ze stałym wydatkiem, odwiert nie jest zamykany w celu odbudowy ciśnienia, a jedynie wymienia się zwężkę tak, że końcowe ciśnienie przypływu poprzedniego cyklu jest ciśnieniem początkowym cyklu następnego.

Również i ten rodzaj testu produkcyjnego powinien być poprzedzony okresem odbudowy ciśnienia w celu ustalenia średniego ciśnienia złożowego lub średniego ciśnienia w obszarze drenażu $(\bar{p})$, chyba że wielkość tę można wiarygodnie ustalić na podstawie innych pomiarów.

\section{Zmodyfikowany sposób przeprowadzania i interpretacji wielocyklowego testu produkcyjnego odwiertu gazowego}

Stosowane metody wykonywania i interpretacji tradycyjnych testów produkcyjnych opisano w skrócie we wstępie. Ich celem jest ustalenie możliwości wydobywczych odwiertu gazowego, to jest określenie wielkości przypływu gazu przy danej depresji, co umożliwia planowanie eksploatacji danego odwiertu.

Interpretacja testów produkcyjnych oparta jest na teoretycznej zależności określanej mianem „formuły dwuczłonowej”, podanej wzorem (1) lub (4). Jeżeli $a$ i $b$ są znane, to możliwe jest podanie wielkości wydobycia potencjalnego przy danej depresji, czyli zaplanowanie eksploatacji odwiertu.

W praktyce wyrażenia (1) lub (4) nie zawsze dobrze opisują zależność pomiędzy wydatkiem przepływu $Q_{i}$ a ciśnieniem dennym ruchowym $p_{d r i}$, co przypisać należy:

- wytrącaniu się kondensatu w strefie przyotworowej w wyniku zmian ciśnienia i temperatury;
- różnicom w przepuszczalności pomiędzy strefą przyodwiertową a złożem;

- instalowaniem filtrów zapobiegających wynoszeniu piasku;

- rozmaitym sposobom udostępnienia złoża (perforacja lub otwór nieorurowany),

co sprawia, że często jeden lub więcej punktów pomiarowych należy odrzucić, jeżeli jego współrzędne odbiegają znacznie od liniowego trendu zależności $\left(\bar{p}^{2}-p_{d r_{i}}^{2}\right) / Q_{i}$ vs. $Q_{i}$.

W takich przypadkach Szpunar i Budak (2016) (rozwinięcie prac tych samych autorów z lat 2007, 2008, 2015) zaproponowali użycie zmodyfikowanej zależności (4) w postaci:

$$
\bar{p}^{2}-p_{d r_{i}}^{2}=a Q_{i}+b Q_{i}^{n}
$$

$\mathrm{W}$ (5) występują trzy wielkości niewiadome, tj. $a, b$ i $n$ w odróżnieniu od formuły dwuczłonowej (4), w której niewiadomymi są jedynie $a$ i $b$, czyli jedyną różnicą jest przyjęcie, że $n$ może być różne od 2, ale może być również równe 2 , jeżeli tak wykażą pomiary.

Podstawy teoretyczne procedury obliczeń $a, b$ i $n$ zaprezentowano w pracy Szpunara i Budaka (2016), natomiast poniżej podano kolejno czynności, jakie należy wykonać przy realizacji i interpretacji omawianego testu produkcyjnego.

1) Uruchamiamy eksploatację odwiertu gazowego $\mathrm{z}$ wydatkiem $Q_{i}$ i rejestrujemy odpowiadające mu ciśnienie denne ruchowe $p_{d r i}$.

2) Zamykamy odwiert i czekamy na stabilizację ciśnienia dennego do poziomu średniego ciśnienia w obszarze drenażu odwiertu $\bar{p}^{2}$ (lub początkowego ciśnienia złożowego $p_{o}$, jeżeli odwiert jest nowy).

3) Powtarzamy czynności podane w punktach 1 i 2, przyjmując, że $Q_{N}$ równe jest maksymalnemu planowanemu wydatkowi przypływu gazu.

4) Przeprowadzamy serię kolejnych cykli przypływu z wydajnościami pośrednimi przypływu gazu obliczonymi za pomocą wzoru:

$$
Q_{N-i}=Q_{1}\left(\frac{i}{N-1}\right) Q_{N}\left(1-\frac{i}{N-1}\right)
$$

5) Rejestrujemy ustabilizowane ciśnienie denne ruchowe odpowiadające każdej z obliczonych wydajności. Po zakończeniu każdego z cykli przypływu należy odwiert zamknąć i zaczekać na odbudowę ciśnienia dennego do średniego ciśnienia w obszarze drenażu w przypadku odwiertów eksploatowanych wcześniej lub początkowego ciśnienia złożowego w przypadku odwiertów nowych.

6) Dla każdego cyklu przypływu obliczamy $C_{i}$.

$$
C_{i}=\frac{\bar{p}^{2}-p_{d r_{i}}^{2}}{Q_{i}}
$$

gdzie $i=1,2, \ldots, N$.

7) Obliczamy $a$ ze wzoru: 


$$
a=\frac{1}{N-2} \sum_{i=1}^{N-2} \frac{C_{i} C_{i+2}-C_{i+1}^{2}}{C_{i}+C_{i+2}-2 C_{i+1}}
$$

gdzie $i=1,2, \ldots, N-2$

Od tego momentu można postępować w dwojaki sposób, to jest zastosować metodę graficzną lub analityczną do określenia $a, b$ i $n$. Metoda graficzna określania wszystkich współczynników równania (5) wraz z przykładami obliczeń podana została przez Szpunara i Budaka (2016) w ich pracy. W niniejszym artykule ograniczymy się do zaprezentowania metody analitycznej, która sprowadza się do wykonania następujących działań:

8) Znając wielkość $a$, obliczamy $n$ za pomocą zależności:

$$
n=1+\frac{1}{N-1} \sum_{i=1}^{N-1} \frac{\log \frac{C_{i}-a}{C_{i+1}-a}}{\log \frac{Q_{i}}{Q_{i+1}}}
$$

Tabela 1. Zestawienie wyników obliczeń

\begin{tabular}{|c|c|c|c|c|c|}
\hline & $\begin{array}{c}\text { Laminarny współczynnik } \\
\text { przypływu } a\end{array}$ & $\begin{array}{c}\text { Turbulentny współczynnik } \\
\text { przypływu } b\end{array}$ & \multirow[t]{2}{*}{ Wykładnik $n$} & $\begin{array}{c}\text { Wydatek } \\
\text { potencjalny } Q_{a b s}\end{array}$ & \multirow{2}{*}{$\sum R^{2}$} \\
\hline & $\mathrm{MPa} /\left(\mathrm{Nm}^{3} / \mathbf{m i n}\right)$ & $\mathrm{MPa} /\left(\mathrm{Nm}^{3} / \mathrm{min}\right)^{2}$ & & $\mathrm{Nm}^{3} / \mathrm{min}$ & \\
\hline \multicolumn{6}{|l|}{ Odwiert J-4 } \\
\hline Metoda A & 0,0057 & 0,00026 & 1,8826 & 2471,07 & 0,00001 \\
\hline Metoda std. & 0,0070 & 0,00014 & 2 & 2133,74 & 0,00003 \\
\hline \multicolumn{6}{|l|}{ Odwiert K-1 } \\
\hline Metoda A & 0,0245 & 0,00009 & 2,0612 & 1957,03 & 0,0443 \\
\hline Metoda std. & 0,0226 & 0,00014 & 2 & 1975,49 & 0,0606 \\
\hline \multicolumn{6}{|l|}{ Odwiert $K-2$} \\
\hline Metoda A & 0,9686 & 0,0160 & 1,8388 & 163,14 & 0,9184 \\
\hline Metoda std. & 1,0414 & 0,0169 & 2 & 160,30 & 2,0431 \\
\hline \multicolumn{6}{|l|}{ Odwiert $K-10$} \\
\hline Metoda A & 0,3114 & 0,00049 & 2,2322 & 477,41 & 14,8807 \\
\hline Metoda std. & 0,2808 & 0,00084 & 2,0 & 508,27 & 18,6058 \\
\hline \multicolumn{6}{|l|}{ Odwiert P-1 } \\
\hline Metoda A & 0,6230 & 0,00010 & 2,4365 & 238,56 & 3,1055 \\
\hline Metoda std. & 0,5713 & 0,00013 & 2 & 241,55 & 3,4966 \\
\hline \multicolumn{6}{|l|}{ Odwiert R-4 } \\
\hline Metoda A & 0,0933 & 0,0004 & 1,5709 & 1111,42 & 0,0297 \\
\hline Metoda std. & 0,0848 & 0,0003 & 2 & 1411,57 & 0,0346 \\
\hline \multicolumn{6}{|l|}{ Odwiert S-5 } \\
\hline Metoda A & 1,1010 & 0,02866 & 2,1259 & 63,01 & 64,21 \\
\hline Metoda std. & 1,2830 & 0,04201 & 2 & 66,52 & 111,81 \\
\hline \multicolumn{6}{|l|}{ Odwiert S-8 } \\
\hline Metoda A & 0,1959 & 0,00089 & 1,9816 & 1063,97 & 0,0566 \\
\hline Metoda std. & 0,1969 & 0,00081 & 2 & 1048,42 & 0,0530 \\
\hline \multicolumn{6}{|l|}{ Odwiert $W-4$} \\
\hline Metoda A & 0,1403 & 0,0004 & 2,4703 & 771,55 & 0,1859 \\
\hline Metoda std. & 0,1301 & 0,00045 & 2 & 1065,60 & 0,3374 \\
\hline \multicolumn{6}{|l|}{ Odwiert Z-7 } \\
\hline Metoda A & 1,0266 & 0,0603 & 2,0163 & 85,80 & 68,10 \\
\hline Metoda std. & 1,1521 & 0,0597 & 2 & 88,15 & 134,75 \\
\hline
\end{tabular}

Table 1. Summary of calculation results

W tabeli $\sum R^{2}$ oznacza sumę kwadratów odległości punktów pomiarowych od prostej aproksymującej

Metoda A - obliczono według Szpunar i Budak (2016) 
9) Znając wielkość $n$, obliczamy $b$ z równania:

$$
b=\frac{1}{N} \sum_{i=1}^{N} \frac{C_{i}-a}{Q_{i}^{n-1}}
$$

Warunkiem stosowalności podanej powyżej procedury jest, aby natężenie przepływu gazu każdego cyklu przypływu spełniało warunek:

$$
Q_{i+1}=\sqrt{Q_{i} Q_{i+2}}
$$

czyli natężenie przypływu każdego cyklu powinno być równe średniej geometrycznej natężenia przypływu cyklu poprzedzającego i następującego po danym cyklu przypływu, co wymaga użycia zwężki regulowanej.

Poniżej podano wyniki wielocyklowego testu produkcyjnego zinterpretowane za pomocą powyżej podanej metody dla 10 odwiertów gazowych z krajowego przemysłu naftowego oraz porównanie wyników tej metody z wynikami otrzymanymi przy użyciu standardowej metody interpretacji testów produkcyjnych. Spośród wielu zestawów danych autorzy znaleźli kilkanaście, dla których spełniony był warunek (11).

Analizując wyniki porównania obydwu metod, można skonstatować akceptowalną zgodność laminarnych współczynników przepływu $a$ oraz względnie umiarkowaną współczynników turbulencji przypływu $b$, akceptowalną wykładnika $n$ oraz akceptowalną zgodność pomiędzy wydobyciem potencjalnym odwiertów obliczonym obydwiema tymi metodami, co przedstawiono w sposób graficzny na rysunkach od 1 do 3 . W każdym przypadku dopasowanie wyników obliczeń do danych pomiarowych jest lepsze przy zastosowaniu proponowanej metody, a ponieważ dopuszcza różną od 2 wielkość wykładnika $n$, można ją uznać za bardziej dokładną.

Opisana powyżej metoda w dalszym ciągu wymaga zamykania odwiertu w celu odbudowy ciśnienia, co jest kosztowne i czasochłonne oraz przynosi straty ekonomiczne. W przypadku

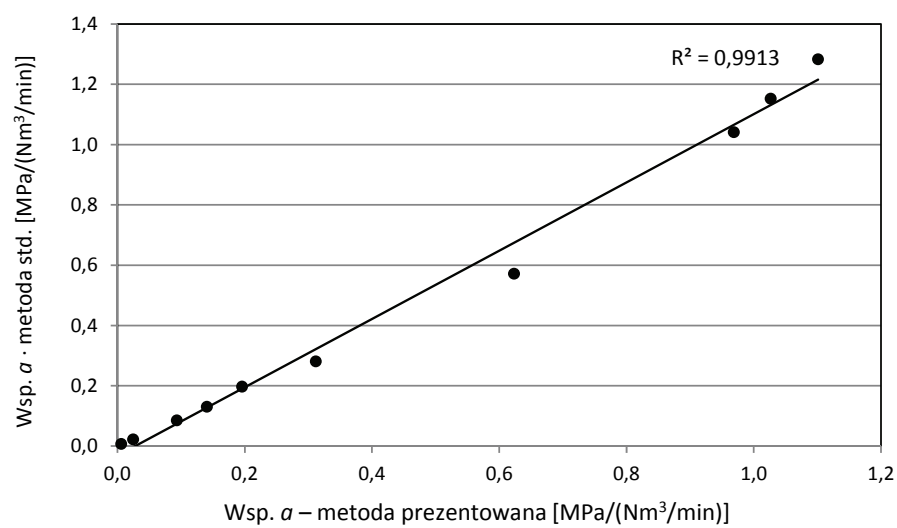

Rys. 1. Korelacja laminarnego współczynnika przypływu $a$ obliczonego prezentowaną metodą i metodą standardową

Fig. 1. Correlation of laminar flow coefficient $a$ calculated using presented method and standard method

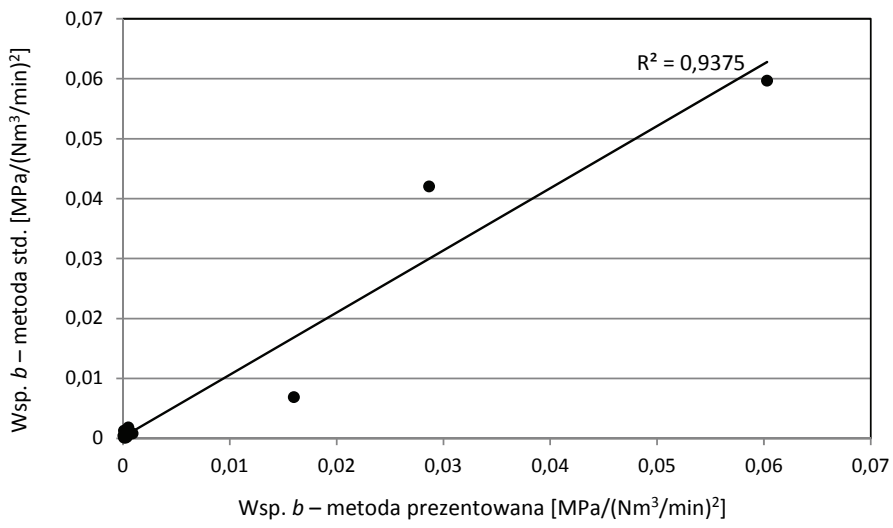

Rys. 2. Korelacja turbulentnego współczynnika przypływu $b$ obliczonego prezentowaną metodą i metodą standardową

Fig. 2. Correlation of turbulent flow coefficient $b$ calculated using presented method and standard method

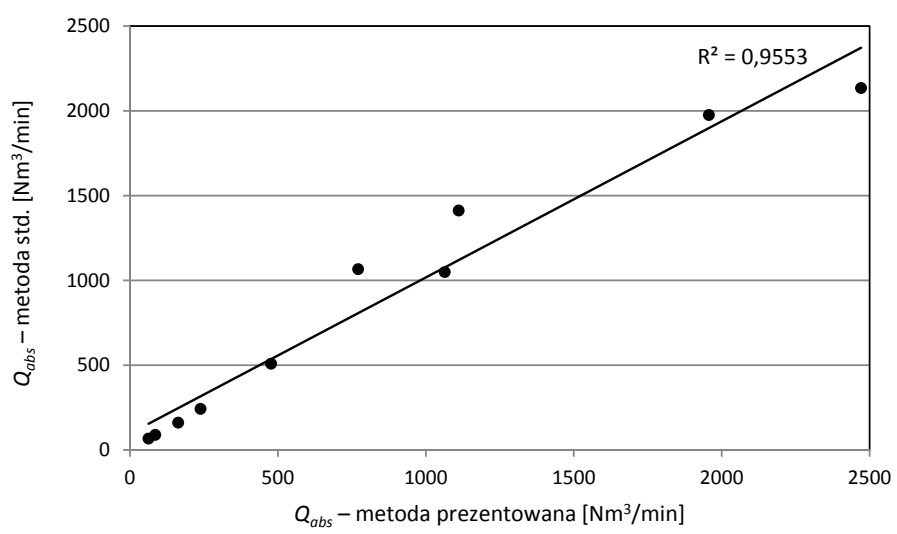

Rys. 3. Korelacja wydatku potencjalnego obliczonego prezentowaną metodą i metodą standardową

Fig. 3. Correlation of open flow potential calculated using presented method and standard method

omawianego testu (opracowanego przez autorów) można jednak zastosować procedurę wykonywania pomiarów opisaną przy przedstawianiu zmodyfikowanego testu izochronicznego, co ograniczy czas trwania opisywanej procedury do minimum i ograniczy koszty przestoju odwiertu gazowego. W dalszej części artykułu podane zostały sposoby uproszczone aktualizacji postaci formuły dwuczłonowej niewymagające zamykania odwiertu w celu odczytu ciśnień ustabilizowanych dennych odpowiadających danym wydatkom przypływu gazu.

\section{Uproszczone sposoby uaktualniania wielkości współczynnika przepływu laminarnego niewymagające przerywania eksploatacji odwiertu}

W miarę eksploatacji odwiertu gazowego zmienia się zarówno średnie ciśnienie złożowe w obszarze drenażu, jak i współczynniki $a$ i $b$ formuły dwuczłonowej będące funkcją tego ciśnienia. Zmienność współczynnika przepływu laminarnego $a$ jest stosunkowo szybka, natomiast współczynnik $b$ zmienia się 
bardzo wolno. W literaturze (Donohue, 1990) znaleźć można stwierdzenie, że przy pseudoustalonym stanie przypływu, a zatem w praktyce przez cały czas eksploatacji złoża, wielkość $b$ można przyjąć jako stałą.

\section{Sposób I}

Jeżeli na podstawie wcześniej wykonywanych testów znamy wielkość współczynnika przepływu turbulentnego $b$ oraz dysponujemy wiarygodną oceną średniego ciśnienia złożowego w obszarze drenażu odwiertu, określoną np. na podstawie wielkości spadku ciśnienia przypadającej na znaną objętość wydobytego gazu, to jedyną wartością nieznaną równania (4) jest współczynnik przepływu laminarnego $a$. Współczynnik ten dla stanu pseudoustalonego można wyrazić prostą zależnością analityczną (Dake, 1978):

$$
\begin{aligned}
& a\left[\frac{\mathrm{MPa}^{2}}{\mathrm{Nm}^{3} / \mathrm{min}}\right]=0,8825 \frac{T(K) \mu_{g}(T, \bar{p})(\mathrm{cP}) \mathrm{Z}(\bar{p}, \mathrm{~T})}{K(m D) h(m)} \\
& \left(\ln \frac{4 A\left(m^{2}\right)}{(1,781) C_{A} r_{w}^{2}(m)^{2}}+S\right)
\end{aligned}
$$

gdzie:

$T$ - temperatura złożowa [K],

$\mu_{g}-$ lepkość gazu [cP],

$Z$ - współczynnik uwzględniający odstępstwa zachowania gazu od zachowania gazu idealnego [-],

$K$ - przepuszczalność złoża [mD],

$h$ - miąższość złoża [m],

A - pole powierzchni drenażu odwiertu $\left[\mathrm{m}^{2}\right]$,

$C_{A}-$ współczynnik kształtu [-],

$R_{w}-$ promień odwiertu [m],

$S-$ skin efekt [-].

Zdaniem autorów wzór (12), określający wielkość współczynnika przepływu laminarnego $a$, ma jedynie znaczenie teoretyczne z uwagi na brak wiarygodnej znajomości występujących w nim wielkości. Zgodnie ze wzorem (12) współczynnik $a$ zależy od średniego ciśnienia złożowego $\bar{p}$, które maleje w miarę eksploatacji gazu, co powoduje spadek temperatury $T$ oraz zmianę lepkości gazu, będącej funkcją ciśnienia i temperatury. Od temperatury i ciśnienia zależy również wielkość współczynnika $Z$, który uwzględnia odstępstwa zachowania gazu od zachowania gazu idealnego i który również zależy od ciśnienia i temperatury. Na wielkość $a$ wpływa także wielkość skin efektu $S$, który może zmieniać się w trakcie eksploatacji złoża w wyniku wytrącania się osadów w strefie przyodwiertowej spowodowanego spadkiem temperatury i ciśnienia. Również pozostałe wielkości, takie jak pole powierzchni $A$ obszaru drenowanego przez eksploatowany odwiert, jak i współczynnik kształtu tego obszaru $C_{A}$, którego ustalenie wymaga znajomości kształtu tego obszaru i przypisania go do określonej figury geometrycznej, można określić jedynie w przybliżeniu. Każda zmiana wydajności przypływu gazu w odwiertach sąsiadujących, podobnie jak uruchomienie i zamknięcie dowolnego odwiertu na eksploatowanym złożu, powoduje zmianę zarówno pola powierzchni drenowanego obszaru $A$, jak i kształtu i położenia na nim rozpatrywanego odwiertu, a zatem zmianę współczynnika kształtu $C_{A}$. W celu przybliżenia wielkości $a$ w przypadku złóż jednorodnych o stałej miąższości, dla których można dokładnie określić wielkości $A$ i $C_{A}$, siatka odwiertów jest regularna, znane jest średnie ciśnienie w obszarze drenażu i można wiarygodnie przybliżyć pozostałe wartości występujące we wzorze (12) w funkcji średniego ciśnienia złożowego i temperatury, można skorzystać z tej zależności w celach orientacyjnych.

\section{Sposób II}

Narzucającym się i najprostszym z możliwych sposobem przybliżonego określenia wielkości współczynnika przepływu laminarnego $a$ oraz średniego ciśnienia złożowego jest sposób podany poniżej.

W miarę eksploatacji złoża gazu spada średnie ciśnienie złożowe i zmieniają się wszystkie zależne od niego wielkości, jak lepkość gazu, temperatura złożowa czy współczynnik $Z$. Powoduje to, że ustalona wcześniej na podstawie testów postać formuły dwuczłonowej przestaje obowiązywać, przy czym dotyczy to szczególnie współczynnika przepływu laminarnego $a$. Wielkość współczynnika przepływu turbulentnego $b$ jest bardzo mało podatna na zmiany wymienionych parametrów i dla pseudoustalonego stanu przypływu (czyli praktycznie przez cały czas eksploatacji złoża) jego wielkość można przyjąć za stałą (Dake, 1978). W przypadku gdy pomiary wykonano niedawno, wartość $b$ jest przyjmowana jako równa poprzednio ustalonej. Istniejące przepisy wymagają okresowego uaktualniania postaci formuły dwuczłonowej, co jest konieczne do oceny możliwości produkcyjnych całego złoża i poszczególnych odwiertów. Wykonanie okresowych testowań, w tym:

- klasycznych testów produkcyjnych;

- testów izochronicznych;

- zmodyfikowanych testowań izochronicznych,

wymaga zamykania odwiertu na czas potrzebny do odbudowy ciśnienia lub czas równy czasowi przypływu gazu w danym cyklu przypływu, a zatem przerwania eksploatacji na pewien okres. W przypadku złóż o małej przepuszczalności czas wymagany do ustabilizowania się ciśnień odbudowy i przypływu może być bardzo długi, co powoduje straty ekonomiczne.

Jeżeli istnieją podstawy, aby sądzić, że ustalona wcześniej postać formuły dwuczłonowej przestała obowiązywać, lub gdy wymagają tego przepisy, to zakładając stałość wartości współczynnika $b$, można określić współczynnik $a$, wykonując 
pojedynczy cykl przypływu gazu z wydajnością różną od wydajności aktualnej, czyli przez prostą zmianę średnicy zwężki. Zakładamy, że odwiert eksploatowany jest aktualnie z ustabilizowaną wydajnością $Q_{\text {lstab }}$ a ustabilizowane ciśnienie denne ruchowe wynosi $p_{d r l s t a b}$. Wymienione wielkości są znane podczas eksploatacji gazu, a wielkość $p_{\text {dr rstab }}$ można w razie potrzeby określić na podstawie odczytanego ciśnienia głowicowego ruchowego $p_{\text {gllstab }}$. Zgodnie z proponowaną procedurą zmienia się następnie wydatek gazu i po czasie potrzebnym do stabilizacji ciśnień odczytuje się nowy wydatek $Q_{2 s t a b}$ oraz nowe ustabilizowane ciśnienie denne ruchowe $p_{d r 2 s t a b}$. Dla każdej pary wartości ustabilizowanego wydatku $Q_{\text {stab }}$ i ciśnienia dennego ruchowego $p_{\text {drstab }}$ obowiązuje równanie formuły dwuczłonowej, możemy zatem napisać:

$$
\begin{aligned}
& \bar{p}^{2}-p_{d r_{1 s t a b}}{ }^{2}=a^{\prime} Q_{1 s t a b}+b Q_{1 s t a b}{ }^{2} \\
& \bar{p}^{2}-p_{d r_{2 s t a b}{ }^{2}}=a^{\prime} Q_{2 s t a b}+b Q_{2 s t a b}{ }^{2}
\end{aligned}
$$

Jeżeli przyjąć, że $b$ znane jest z poprzednich pomiarów, to wielkościami nieznanymi w układzie równań (13) i (14) jest zatem średnie ciśnienie w obszarze drenażu odwiertu ( $p$ oraz aktualny współczynnik przepływu laminarnego $a$ formuły dwuczłonowej. Rozwiązując powyższy układ równań, otrzymamy:

$a^{\prime}\left[\frac{\mathrm{MPa}^{2}}{\mathrm{Nm}^{3} / \mathrm{min}}\right]=\frac{p_{d r_{2 s t a b}}^{2}-p_{d r_{1 s t a b}}^{2}}{Q_{1 s t a b}-Q_{2 s t a b}}-b\left(Q_{1 s t a b}-Q_{2 s t a b}\right)$

oraz

$$
\begin{aligned}
& \bar{p}[\mathrm{MPa}]= \\
& =\sqrt{\frac{p_{d r_{2 s t a b}}^{2} Q_{1 s t a b}-p_{d r_{1 s t a b}} Q_{2 s t a b}}{Q_{1 s t a b}-Q_{2 s t a b}}-b Q_{1 s t a b} Q_{2 s t a b}}
\end{aligned}
$$

W przypadku posługiwania się pseudociśnieniami należy $p^{2}$ we wzorach (15) i (16) zastąpić przez $m(\bar{p})$.

Jeżeli ponownie przełączylibyśmy wydatek przypływu gazu na nową wielkość $Q_{3 s t a b}$ i odczytali odpowiadające $Q_{3 s t a b}$ ustabilizowane ciśnienie denne ruchowe $p_{d r 3 s t a b}$, to otrzymalibyśmy układ trzech równań z trzema niewiadomymi, tj. średnim ciśnieniem w obszarze drenażu $\bar{p}$ oraz współczynnikami $a$ i $b$. Przedstawiony sposób kolejnego zmieniania wydatków przepływu gazu może być kontynuowany przez kolejne zmienianie zwężek i rejestrowanie odpowiadających sobie $Q_{\text {Nistab }}$ i $p_{\text {dristab }}$ dla $i=1, \ldots, n$, gdzie $n$ to liczba cykli przypływu. Ten rodzaj testowań niewymagający zamykania odwiertu i oczekiwania na stabilizację ciśnienia odbudowy podobny jest do skróconego flow after flow test. W przypadku gdy liczba wykonywanych cykli jest większa od 3, czyli od liczby niewiadomych $(\bar{p}, a \mathrm{i} b)$, to do określenia tych wielkości stosowana jest metoda najmniejszych kwadratów, a jeżeli znane jest średnie ciśnienie złożowe $p$, to do obliczenia $a$ i $b$ można zastosować metodę graficzną i interpretacja sprowadzi się do interpretacji standardowego wielocyklowego testu przypływu gazu. Zastosowanie przedstawionego sposobu jest jednak ograniczone z powodów podanych w dalszej części artykułu.

\section{Przyktad zastosowania sposobu II}

Podany poniżej przykład pochodzi z odwiertu R-4 z krajowego przemysłu naftowego. Odwiert eksploatowany był przy ustalonym wydatku przypływu gazu $Q_{\text {Istab }}=77,2 \mathrm{Nm}^{3} / \mathrm{min}$ oraz ustabilizowanym ciśnieniu dennym ruchowym $p_{\text {dr } r \text { stab }}=25,82 \mathrm{MPa}$. Zmiana zwężki spowodowała zmianę wydatku, który ustabilizował się na poziomie $Q_{2 s t a b}=94,1 \mathrm{Nm}^{3} / \mathrm{min}$ przy ustabilizowanym ciśnieniu dennym ruchowym $p_{\text {pdrastab }}=25,78 \mathrm{MPa}$. Określona podczas poprzednich testowań wielkość współczynnika przepływu turbulentnego $b=0,00028 \mathrm{MPa}^{2} /\left(\mathrm{Nm}^{3} / \mathrm{min}\right)^{2}$. Z wzoru (15) otrzymamy:

$$
a=0,074 \frac{\mathrm{MPa}^{2}}{\mathrm{Nm}^{3} / \mathrm{min}}
$$

a z (16):

$$
\bar{p}=25,96[\mathrm{MPa}]
$$

Podawana przez operatora wartość średniego ciśnienia złożowego w obszarze drenażu odwiertu R-4 wynosiła 25,98 MPa, a otrzymana na podstawie interpretacji klasycznego testu wielocyklowego wartość współczynnika przepływu laminarnego $a=0,0848$ była nieco inna od określonej powyższą metodą. Wielkość wydobycia potencjalnego dla $a$ i $p$ obliczonych powyższą metodą równa jest:

$$
Q_{a b s}=1225,46 \frac{\mathrm{Nm}^{3}}{\mathrm{~min}}
$$

Ustalona na podstawie wykonanego później klasycznego testu wielocyklowego wielkość wydobycia potencjalnego wyniosła $Q_{a b s}=1411 \mathrm{Nm}^{3} / \mathrm{min}$, a więc różniła się o $13 \%$.

Przedstawiona metoda obliczenia ciśnienia złożowego $\bar{p}$ oraz współczynnika przepływu laminarnego $a$ jest bardzo przybliżona. Opiera się ona na założeniu, że ciśnienie $p_{d r}$ oraz natężenie przepływu gazu idealnie spełniają równanie formuły dwuczłonowej $\overline{p^{2}}-p_{d r i}{ }^{2}=a Q_{i}+b Q_{i}^{2}$, co nie zawsze jest prawdą.

Instalowanie w odwiercie filtrów przeciw piaszczeniu, różna od reszty złoża przepuszczalność strefy przyodwiertowej oraz trudność ustalenia ciśnienia dennego ruchowego stabilizacji są czynnikami, która sprawiają, że pomierzone ciśnienie i natężenie wypływu gazu mogą odbiegać od wielkości teoretycznych wynikających z postaci formuły dwuczłonowej. Podobnie wielkości $a$ i $p$ obliczane z pierwszego i drugiego cyklu mogą nieznacznie różnić się od tych samych wielkości wyznaczanych z cyklu drugiego i trzeciego, trzeciego i czwartego itp. 


\section{Sposób III}

Przedstawiony powyżej II sposób ustalenia średniego ciśnienia złożowego $\bar{p}$ w obszarze drenażu oraz współczynnika przepływu laminarnego $a$ jest, jak wynika $\mathrm{z}$ treści poprzedniego rozdziału, rozwiązaniem doraźnym, pozwalającym jedynie na przybliżone uaktualnienie wielkości tych współczynników i ewentualne przedłużenie okresu pomiędzy kolejnymi testowaniami odwiertów. Wada przedstawionego sposobu polega na tym, że obliczany współczynnik $a$ nie jest bezpośrednio funkcją średniego ciśnienia złożowego w obszarze drenażu, które obliczane jest niezależnie. Jak wynika z postaci wzoru (12), określającego teoretyczną wielkość współczynnika $a$, wielkości takie jak pole powierzchni drenażu $A$, współczynnik kształtu $C_{A}$, promień odwiertu $r_{w}$, współczynnik skin efektu $S$, miąższość $h$ i przepuszczalność złoża $k$ są traktowane jako wielkości stałe, tj. niezmieniające się w trakcie eksploatacji, a zatem niewpływające na zmianę wielkości współczynnika $a$. W praktyce średnie ciśnienie $\mathrm{W}$ obszarze drenażu odwiertu wpływa na średnią temperature gazu w złożu $T$, lepkość gazu $\mu$ oraz współczynnik $Z$, czyli przy stałych pozostałych wartościach $A, C_{A}, r_{w}, S, k, h$ jest głównym czynnikiem powodującym zmianę współczynnika $a$. Autorzy proponują następujący sposób uaktualnienia współczynnika przypływu laminarnego $a$ formuły dwuczłonowej, który uwzględnia zależność $a$ od średniego ciśnienia złożowego.

Zakładamy, że:

- współczynnik przypływu turbulentnego $b$ znany jest z poprzednich pomiarów oraz że nie zmienił się w okresie od ostatnich testowań odwiertu;

- odwiert eksploatowany jest aktualnie przy ustabilizowanym ciśnieniu dennym ruchowym $p_{\text {drIstab }}$ i wydatku gazu $Q_{N I s t a b}$, czyli spelnione są warunki pseudoustalonego charakteru przypływu;

- znane jest aktualne średnie ciśnienie złożowe w obszarze drenażu, np. na podstawie wielkości spadku ciśnienia przypadającego na określoną ilość wydobytego gazu. Takie określenie średniego ciśnienia złożowego na podstawie ilości gazu wydobytego od ostatnich pomiarów jest bardzo przybliżone, ale praktykowane i wystarczające do celów inżynierskich;

- uruchomiono wydobycie gazu z nowym wydatkiem i pomierzono ciśnienie denne ruchowe $p_{d r \text { rstab }}$ oraz natężenie wypływu gazu $Q_{N 2 s t a b}$ po uzyskaniu stabilizacji przypływu. Jak wynika z powyższego opisu, czynności wykonywane przy realizacji sposobu III nie różnią się od postępowania podanego przy omawianiu sposobu II, natomiast różnice występują w interpretacji. Dla każdego cyklu przypływu możemy napisać równanie formuły dwuczłonowej w postaci:

$$
\bar{p}^{2}-p_{d r_{1 s t a b}}^{2}=a Q_{N 1 s t a b}+b Q_{N 1 s t a b}^{2}
$$

$$
\bar{p}^{2}-p_{d r_{2 s t a b}}^{2}=a Q_{N 2 s t a b}+b Q_{N 2 s t a b}^{2}
$$

Z (17) i (18) wynika, że:

$$
\left(\frac{Q_{N 1 s t a b}}{Q_{N 2 s t a b}}\right)^{2}=\frac{\bar{p}^{2}-p_{d r_{1 s t a b}}^{2}-a Q_{N 1 s t a b}}{\bar{p}^{2}-p_{d r_{2 s t a b}}^{2}-a Q_{N 2 s t a b}}
$$

skąd otrzymamy:

$$
a=\frac{Q_{N 1 s t a b}^{2}\left(\bar{p}^{2}-p_{d r_{2 s t a b}}^{2}\right)-Q_{N 2 s t a b}^{2}\left(\bar{p}^{2}-p_{d r_{1 s t a b}}^{2}\right)}{Q_{N 1 s t a b}^{2} Q_{N 2 s t a b}-Q_{N 1 s t a b} Q_{N 2 s t a b}^{2}}
$$

Jak wynika z (20), współczynnik przepływu laminarnego $a$ jest funkcją średniego ciśnienia złożowego $p$, a zakładając znajomość współczynnika $b$, można podać postać formuły dwuczłonowej (4). Oczywiście współczynnik $a$ można uzależnić od $p$ na podstawie danych dla pojedynczego cyklu przypływu, ale jego wartość będzie bardzo niedokładna.

\section{Przyktad}

W jednym z odwiertów gazowych w krajowym przemyśle naftowym (poprzednio rozpatrywany jako odwiert R-4) wykonano klasyczny czterocyklowy test mający na celu ustalenie postaci formuły dwuczłonowej i ocenę możliwości produkcyjnych złoża. Ustalono, że współczynniki $a$ i $b$ wynoszą odpowiednio $0,0848 \mathrm{MPa}^{2} /\left(\mathrm{Nm}^{3} / \mathrm{min}\right)$ oraz $0,00028 \mathrm{MPa}^{2} /\left(\mathrm{Nm}^{3} / \mathrm{min}\right)^{2}$, przy założonym średnim ciśnieniu złożowym równym $\bar{p}=25,98 \mathrm{MPa}$. Obliczona wielkość wydobycia potencjalnego wynosiła $Q_{a b s}=1411,57 \mathrm{Nm}^{3} / \mathrm{min}$. Natężenia przypływu

\begin{tabular}{|c|c|c|}
\hline \multirow{2}{*}{ Nr cyklu } & Natężenie przyplywu & Ciśnienie denne ruchowe \\
\hline & {$\left[\mathrm{Nm}^{3} / \mathrm{min}\right]$} & [MPa] \\
\hline 1 & 77,2 & 25,85 \\
\hline 2 & 115,6 & 25,72 \\
\hline
\end{tabular}
gazu oraz odpowiadające ciśnienia denne ruchowe w pierwszym i drugim cyklu przypływu spełniające kryteria stanu pseudoustalonego podano poniżej:

Korzystając z przedstawionego sposobu, otrzymamy $a=0,0901 \mathrm{MPa}^{2} /\left(\mathrm{Nm}^{3} / \mathrm{min}\right)$ oraz wydobycie potencjalne $Q_{a b s}=1561 \mathrm{Nm}^{3} / \mathrm{min}$. Wyniki te nieznacznie odbiegają od uzyskanych wyników klasycznego testu 4-cyklowego, ale otrzymano je jedynie na podstawie danych dla dwóch prezentowanych cykli przypływu. W klasycznym teście wielocyklowym podawane są wyniki uśrednione ze wszystkich cykli przypływu, co jest konsekwencją założeń metody najmniejszych kwadratów. Nieco inne wyniki uzyskano by, korzystając z drugiego i trzeciego cyklu, trzeciego i czwartego oraz z dowolnej ich konfiguracji, z tym że wszystkie otrzymane wyniki obliczeń laminarnego współczynnika przypływu byłyby sobie bliskie, 
podobnie jak wielkość wydobycia potencjalnego. Zaletą podanego sposobu uaktualniania możliwości wydobywczych odwiertu gazowego jest to, że obliczany współczynnik $a$ zależy zarówno od pomierzonych wydatków i ciśnień dennych ruchowych stabilizacji, jak i od średniego ciśnienia złożowego w obszarze drenażu. Jak wynika z zależności (12), czynnikiem, który w pierwszym rzędzie wpływa na zmianę współczynnika $a$, jest średnie ciśnienie w obszarze drenażu, ponieważ zależy od niego temperatura złożowa, lepkość gazu oraz współczynnik $Z$, czyli wielkości, które zmieniają się wraz ze zmianą ciśnienia złożowego. Dane konieczne do skorzystania z przedstawionego sposobu określania wielkości współczynnika $a$ są identyczne jak w poprzedniej metodzie (sposób II), natomiast inny jest ich sposób interpretacji.

Zasadnicze znaczenie dla prezentowanej metody (podobnie jak dla poprzedniej) ma dokładność pomiarów wydatków i ciśnień odpowiadających warunkom stanu pseudoustalonego.

W tabeli 2 przedstawiono porównanie obliczeń współczynników przepływu laminarnego otrzymanych za pomocą standardowej metody interpretacji wielocyklowego testu przypływu gazu, metody proponowanej przez Szpunara i Budaka (2016) oraz za pomocą zależności (20), stwierdzając akceptowalną zgodność wyników.

Jak widać z powyższych wykresów, współczynniki przepływu laminarnego obliczone trzema metodami wykazują akceptowalną zgodność - kwadraty współczynników korelacji są większe od 0,98 .

Tabela 2. Porównanie obliczonych współczynników przepływu laminarnego

Table 2. Comparison of calculated laminar flow coefficients

\begin{tabular}{|c|c|c|c|}
\hline \multirow{2}{*}{ Odwiert } & \multicolumn{3}{|c|}{ Wspólczynnik przepływu laminarnego } \\
& \multicolumn{3}{|c|}{ obliczony metodą } \\
\cline { 2 - 4 } & $\begin{array}{c}\text { analityczną } \\
\text { (wzór (20)) }\end{array}$ & graficzną & standardową \\
\cline { 2 - 4 } & \multicolumn{3}{|c|}{ [Ma/(Nm ${ }^{3} /$ min)] } \\
\hline \hline K-10 & 0,3047 & 0,3114 & 0,2808 \\
\hline K-1 & 0,0203 & 0,0245 & 0,0226 \\
\hline S-5 & 1,3378 & 1,0309 & 1,2830 \\
\hline S-8 & 0,2059 & 0,1959 & 0,1969 \\
\hline W-4 & 0,1235 & 0,1403 & 0,1301 \\
\hline P-1 & 0,6058 & 0,6230 & 0,5713 \\
\hline R-4 & 0,0826 & 0,0933 & 0,0848 \\
\hline K-2 & 1,0541 & 0,9686 & 1,0414 \\
\hline Z-7 & 1,1430 & 1,0266 & 1,1521 \\
\hline J-4 & 0,0072 & 0,0057 & 0,0070 \\
\hline
\end{tabular}

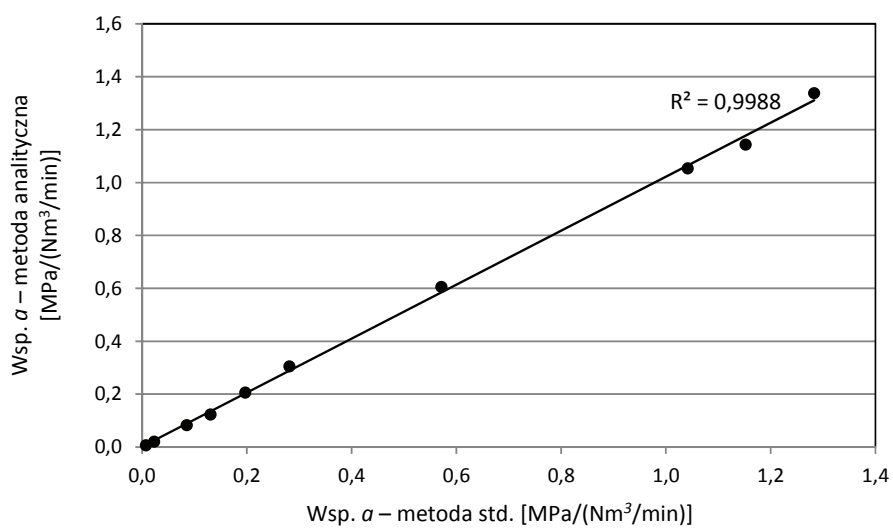

Rys. 4. Korelacja wartości współczynnika $a$ obliczonego metodą standardową oraz analityczną (wzór 20)

Fig. 4. Correlation of coefficient $a$ calculated using standard method and analytical method (equation 20)

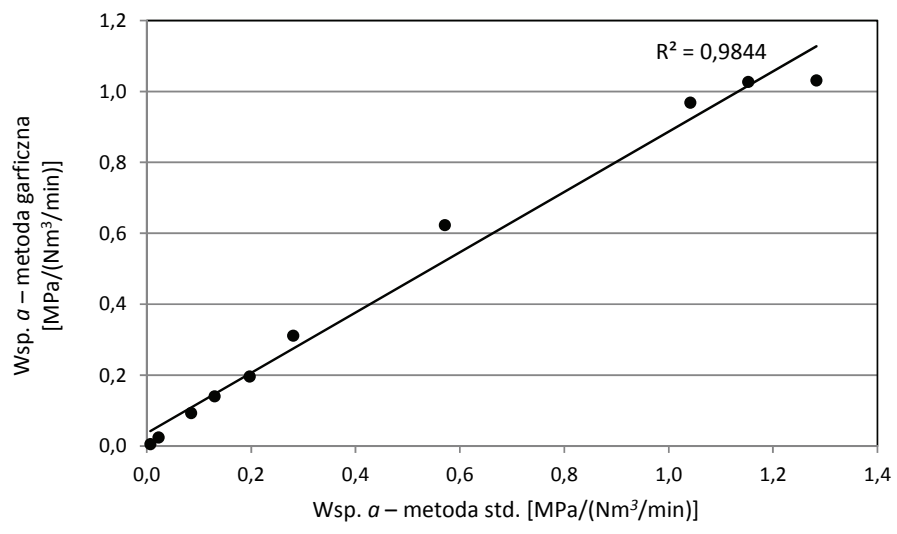

Rys. 5. Korelacja wartości współczynnika $a$ obliczonego metodą standardową oraz graficzną (Szpunar i Budak, 2016)

Fig. 5. Correlation of coefficient $a$ calculated using standard method and graphical method (Szpunar and Budak, 2016)

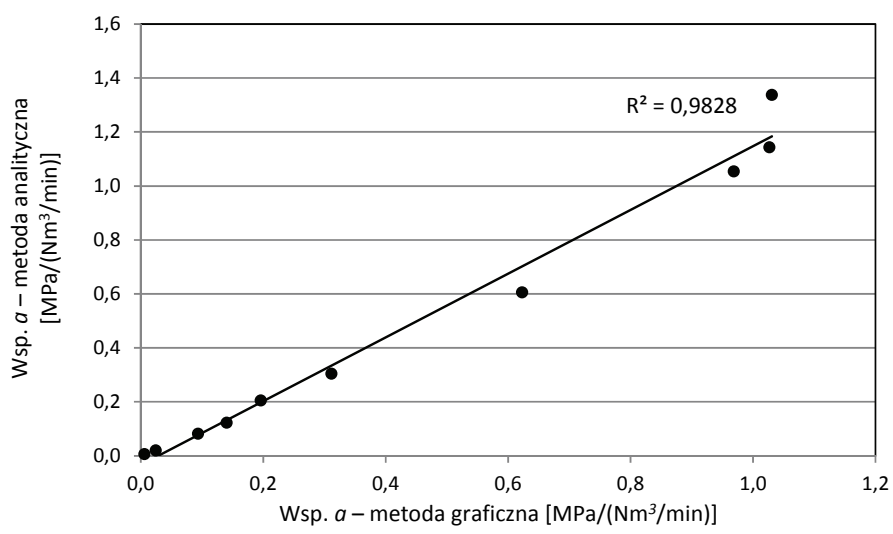

Rys. 6. Korelacja wartości współczynnika $a$ obliczonego metodą graficzną (Szpunar i Budak, 2016) oraz analityczną (wzór (20))

Fig. 6. Correlation of coefficient $a$ calculated using graphical method (Szpunar and Budak, 2016) and analytical method (equation 20) 


\section{Podsumowanie}

W artykule zaproponowano sposoby obliczania współczynnika przepływu laminarnego, co przy znajomości współczynnika przepływu turbulentnego oraz ciśnień, wydatków stabilizacji i średniego ciśnienia złożowego umożliwia obliczenie wydatków przypływu gazu przy określonej depresji wywieranej na złoże oraz pozwala na przedłużenie okresów pomiędzy kolejnymi pomiarami. Porównano wyniki obliczeń współczynnika przepływu laminarnego metodami: standardową (dla klasycznych testów wielocyklowych), zmodyfikowaną (proponowaną przez autorów) oraz za pomocą zależności (20) i stwierdzono akceptowalną zgodność tych wyników. Korzystanie z zależności (20) nie wymaga zamykania odwiertu, a jedynie zmiany natężenia przepływu (zmiana średnicy zwężki). Proponowane sposoby interpretacji mogą być wykorzystane do okresowego uaktualniania postaci formuły dwuczłonowej, co wymagane jest przez przepisy i ze względów technicznych.

Artykuł powstał na podstawie pracy statutowej pt.: Uproszczony sposób uaktualniania charakterystyki wydobywczej odwiertów gazowych przez okresową modyfikację wielkości współczynnika przepływu laminarnego - praca INiG - PIB na zlecenie MNiSW; nr zlecenia: 0070/SI/2019, nr archiwalny: DK-4100-0060/2019.

\section{Literatura}

Dake L.P., 1978. Fundamentals of Reservoir Engineering. Elsevier, Amsterdam-Oxford-New York.
Donohue D.A.T., 1990. Gaswell Testing. Theory, Practice and Regulation. IHRDC Publishers, Boston.

Szpunar T., Budak P., 2007. Uwagi na temat metodyki interpretacji danych wielocyklowego testu przypływu gazu do odwiertu. Nafta-Gaz, 2: 115-124.

Szpunar T., Budak P., 2008. Weryfikacja zmodyfikowanej metodyki interpretacji wyników wielocyklowych testów odwiertów gazowych na podstawie danych przemysłowych. Nafta-Gaz, 9: 557-564.

Szpunar T., Budak P., 2015. Analityczno-graficzny sposób interpretacji danych testu przypływu cieczy do rurowego próbnika złoża oraz porównanie wyników z otrzymanymi metodą slug test. Nafta-Gaz, 2: 77-86.

Szpunar T., Budak P., 2016. A modified concept for carrying and interpretation of multi rate gas well deliverability testing using flow rate control choke. Nafta-Gaz, 1: 15-22. DOI: 10.18668/ NG2016.01.02.

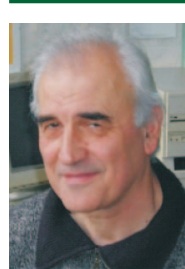

Dr inż. Tadeusz SZPUNAR

Adiunkt w Zakładzie Inżynierii Naftowej

Instytut Nafty i Gazu - Państwowy Instytut Badawczy ul. Lubicz $25 \mathrm{~A}$

31-503 Kraków

E-mail: tadeusz.szpunar@inig.pl

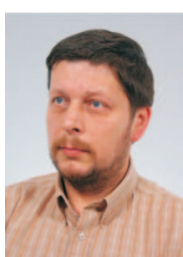

Mgr inż. Paweł BUDAK

Starszy specjalista naukowo-badawczy, kierownik Zakładu Inżynierii Naftowej Instytut Nafty i Gazu - Państwowy Instytut Badawczy ul. Lubicz 25 A

31-503 Kraków

E-mail: pawel.budak@inig.pl

\section{OFERTA BADAWCZA ZAKŁADU INŻYNIERII NAFTOWEJ}

analiza przyczyn oraz badania stopnia uszkodzenia skał zbiornikowych w strefie przyotworowej; ocena gtębokości infiltracii fazy ciektej do skat zbiornikowych

ocena wpływu roztworów soli i cieczy wiertniczych na skały ilaste strefy przyotworowe

pomiary parametrów reologicznych cieczy i niektórych ciat statych w zakresie temperatur od -40 do $200^{\circ} \mathrm{C}$ oraz ciśnień do 150 bar:

badania oraz dobór cieczy roboczych i solanek do prac związanych z opróbowaniem i rekonstrukcją odwiertów: ocena stateczności ścian otworów wiertniczych;

określanie zdolności produkcyjnej odwiertów;

symulacja eksploatacii kawernowych podziemnych magazynów gazu w wysadach solnych, z uwzględnieniem konwergencji komór;

zastosowanie technologii mikrobiologicznych do stymulacii odwiertów oraz usuwania osadów parafinowych w odwiertach i instalacjach napowierzchniowych

projektowanie zabiegów mikrobiologicznej intensyfikacji wydobycia ropy (MEOR);

projektowanie zabiegów odcinania doptywu wód złożowych do odwiertów;

określanie nieredukowalnego nasycenia próbek skaty wodą złożową;

testy zawadniania z użyciem wody, solanki lub $\mathrm{CO}_{2}$;

fotograficzne dokumentowanie rdzeni wiertniczych;

określanie właściwości mechanicznych oraz sejsmoakustycznych skat w próbach okruchowych;

analiza zjawisk migracij i ekshalacii gazu ziemnego oraz występowania ciśnień w przestrzeniach międzyrurowych; modelowanie obiektów ztożowych i opracowywanie specjalistycznego oprogramowania z zakresu inżynierii naftowej.

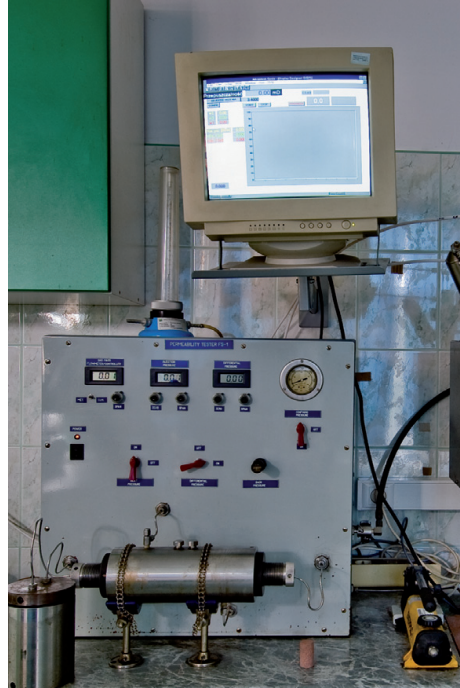

INSTYTUT NAFTY I GAZU

- Państwowy Instytut Badawczy 